\title{
Sport Sponsorship as Cross-sectoral Collaboration and its Value for Young Customers
}

doi: http://dx.doi.org/10.12775/JCRL.2020.002

\section{DOMINIKA MiROŃSKA}

Warsaw School of Economics, Warsaw, Poland

e-mail: dominika.mironska@sgh.waw.pl

\section{AntTi Bergman}

Aalto University School of Busines, Mikkeli, Finland

\begin{abstract}
Purpose: The article discusses the benefits for companies and their customers as a result of collaboration with sport clubs on different advancement stages.
\end{abstract}

Design/methodology/approach: The research takes a quantitative approach to study customers' attitudes towards sponsorship in sports. The survey measures customers' attitudes grouped in three categories: brand favourability, use of products, and perceived social input. It shows how these values change in different collaboration stages, defined by Austin's (2000) Collaboration Continuum.

Findings: The benefits were most effectively created on the philanthropic and integrative stages of collaboration with no statistically significant difference between the two. Further analysis of the results suggested the integrative stage to be the most favourable for companies to collaborate in, when taking into account the overall effect of collaboration.

Research and practical implications: The research provides insight for both, business and non-profit managers in order to gain better 
understanding of the benefits of collaboration and what stage of collaboration results in highest perceived benefits.

Originality/value: The research results may help both entities to manage their collaboration relationships. For non-profits this means understanding the value of their partnership and this way helping to create value propositions. For businesses this means the ability to engage in collaboration that brings best value for their customers and the company.

Paper type: Research paper.

Keywords: cross-sectoral collaboration, CSR in sports, sport sponsorship.

\section{Introduction}

An increasing popularity of sports as a means for achieving marketing objectives by companies has been driven by a rapid development of media along with sports growth into a social phenomenon that appeals to large masses (Maldonado-Erazo et al., 2019). For example, media coverage from 2016 Summer Olympic in Rio de Janeiro was consumed by nearly half of the population in the world (International Olympic Committee Marketing Report, 2016). This makes sports a great platform to reach target audiences and have an effect on consumers attitudes towards the brand thus furthering companies' objectives.

Cross-sectoral collaboration in sports can happen in multiple forms. For marketing and fundraising purposes there has been identified three main approaches for collaboration: cause related marketing, consumer fundraising and sponsorship (Heyman, 2011). According to MaldonadoErazo et al. (2019) sponsorship is a mutual benefit trade agreement between the sponsor and the sponsored in order to achieve objectives defined by both parties.

Until the 1980s this term was used interchangeably with patronage (Meenaghan, 1991) and was associated with the sponsored party's goals fulfilment as a main function. Gradually, the concept of sponsorship evolved towards commercial and social sponsorship (Seitanidi et al., 2007). The commercial type of sponsorship is about supporting business goals, such as increasing brand or company awareness and enhancing sales, and can be performed between business partners as well as between a company and a non-profit organization. The social sponsorship refers to including social goals in business strategies as an 
element of corporate social responsibility. This type of sponsorship is only possible between a business entity and a non-profit organization (Setanidi et al., 2007). Supporting sports may further corporate social responsibility in multiple ways, for example by promoting communities health and helping people to move more themselves, as researched by Ramchandani et al. (2017). In the study it was exhibited that participating to sport events as a spectator can evoke the desire to participate to sports themselves while discouraging factors were not discovered.

Regardless of the type, sport sponsorship expenditures are rapidly growing. In 2014, the global sponsorship spending was estimated up to 55.3 billion USD (IEG Sponsorship, 2015), and for 2017 this number was already up to 62.7 billion USD (Maldonado-Erazo et al., 2019). This creates a lot of opportunities for companies, but today's managers must have the knowledge how to maximize the value from these collaborations. In the next points sponsorship on different levels is researched and analysed as a means for achieving various benefits perceived by companies' customers.

\section{Cross-sectoral collaboration on different stages of advancement}

Cross-sectoral collaboration between business and non-profit organizations is viewed as relations where partners are not only benefitting from each other's resources, but also effectively utilize each other's competences and learn how to create social value (Le Ber \& Branzei, 2010).

Collaboration between business and non-profit organizations can be performed on different levels of advancement. Austin (2000) introduced a Collaboration Continuum in order to help analysing the relationship between the two parties. The model identifies seven key elements of each collaboration to determine the quality and type of the relationship. As presented in Figure 1 these elements are: level of engagement, importance to mission, magnitude of resources, scope of activities, interaction level, managerial complexity and strategic value. Each element is assessed individually on a dynamic scale from low or small to high or large. Collaborations move dynamically along these lines, but to make categorizing and comparing easier, the 


\begin{tabular}{|c|c|c|c|}
\hline $\begin{array}{l}\text { Relationship } \\
\text { stage }\end{array}$ & $\begin{array}{l}\text { One } \\
\text { Philanthropic » }\end{array}$ & $\begin{array}{l}\text { Two } \\
\text { Transactional } "\end{array}$ & $\begin{array}{l}\text { Three } \\
\text { Integrative }\end{array}$ \\
\hline Level of engagement & Low» & $» »$ & » High \\
\hline Importance to mission & Peripheral » & $» "$ & » Strategic \\
\hline Magnitude of resources & Small » & $» "$ & » Big \\
\hline Scope of activities & Narrow » & $» "$ & » Broad \\
\hline Interaction level & Infrequent » & $» "$ & » Intensive \\
\hline Managerial complexity & Simple » & $» »$ & » Complex \\
\hline Strategic value & Modest » & $» "$ & » Major \\
\hline
\end{tabular}

Figure 1. Collaboration Continuum - the three levels of cross-sectoral collaboration Source: Austin (2000).

Collaboration Continuum has been divided into three relationship stages: philanthropic, transactional, and integrative. ${ }^{1}$

Philanthropic stage is the first and less developed stage of collaboration. This stage requires minimal effort and maintenance from both sides and may be limited to the company charitable giving with no further expectations. It should be noted, however, that even with low interaction and complexity, important goals for both sides can be achieved. As stated by Seitanidi and Austin (2014, p. 68.), "there is basic resource complementarity in that the company has money that the non-profit needs, and the non-profit has the ability to deliver some social good or service that the company deems worthy. Each partner provides inputs, but largely independently of the other.” For companies this kind of cooperation may be an easy option to contribute to societal issues and causes without coming overly involved or required to maintain the relationship (Mcdonald \& Young, 2012).

When the relationship deepens the collaboration may turn into the transactional stage. In this stage non-profit organizations contribute more and the value of the collaboration flows more evenly to both parties. According to Austin and Seitanidi (2012a, p. 739.), "[t]he partners have linked interests in that creating value for oneself is dependent on creating it for the other”. On the other hand, it has been argued by Selsky

1 Later on, to adapt to the evolving and deepening nature of cross-sectoral collaboration a fourth stage "transformational" has also been used by Seitanidi and Austin (2014). 
and Parker (2010) that companies might enter these relationships mainly for self-interest and not for social causes.

In the third, integrative stage of collaboration, "the partners' missions, people, and activities begin to experience more collective action and organizational integration” (Austin, 2000, p. 71.). Compared to the transactional stage which mainly concentrates on the exchange of resources, in the integrative stage effects of synergy happen and additional value is created, that could not be achieved by either of the partners separately. This value may have multiple forms, it can be social value through social innovations (Le Ber \& Branzei, 2010) or solving public challenges (Bryson et al., 2006).

Traditional sponsorship as a form of partnership between a company and a non-profit has been usually seen to fall into the transactional stage of collaboration continuum (Austin, 2000). Over the years however, it has evolved and broadened, thus different forms of sponsorship can be sorted between philanthropic and integrative stage (Heyman, 2011). These collaborations are usually formed between a company and a sports club, an association hosting sporting event or an individual athlete. Zinger and O'Reilly (2010) introduced a continuum of sponsorship benefits that are produced when the collaboration is moving along the three stages of advancement, similar to Austin's (2000) phases and called patronage, semi-strong sponsorship, and fully functioning sponsorship.

\section{Benefits of cross-sectoral collaboration}

In cross-sectoral collaboration the amount and quality of benefits received by the collaborating partners is called by Murphy et al. (2015) "value creation" and is moderated by many interconnected determinants of relational nature, like mutual alignment, trust, and involvement in the relationship, underlined by effective communication (Lefroy \& Tsarenko, 2013; Parker \& Selsky, 2004, Barroso-Méndez et al., 2016). The determinants for sponsorship response have also been studied by Speed and Thompson (2000) who suggest that consumers perceptions of the sponsor-event fit is important for the response.

When discussing about benefits that collaboration in sports instigate for the companies they usually fall under brand equity category. Brand equity was depicted by Aaker (1991) as a set of brand assets and liabilities linked to a brand, its name and symbol, that add or subtract from the 
value provided by a product or service to a firm and/or to that firm's customer. The effects of sponsorship to brand equity has been studied by different researchers, for example Cornwell et al. (2001), Henseler et al. (2011) and Tsordia et al. (2017), and there is a growing evidence of impact that sponsorship has on brand equity for customers especially (Henseler et al., 2011). In this paper, the perceived benefits studied are grouped into three categories: favourability of the brand, the intention of using the brand's products and perceived social responsibility of the brand. The categories can be measured by checking customers' attitudes that come from three levels according to the tripartite model, or "the ABC" model: affect, behaviour and cognition (Breckler, 1984). In this model, affect part measures feelings towards a subject, behaviour measures readiness for action towards a subject and cognition measures response and belief of what qualities the subject has.

- Favourability of the brand

Customer preferences towards the brand can be seen as the affective part of the attitude. It shows how the sponsorship and exposure through collaboration has changed the customers' opinion about the brand and how they feel about it, whether they see it more favourable or not. These positive feelings build the brand image over time, when the partnership evolves and the businesses' objectives move from building brand awareness to brand image (Cornwell et al., 2001).

- Intention of using the brand

Declaration of readiness to buy and use the brand's products includes the behavioural part of the attitude. It shows whether collaboration makes customers more likely to buy products from the sponsor (Davies et al., 2008). According to Tsordia et al. (2017) sponsorships may impact perceived quality and engagement of products for customers, which might influence purchase behaviour. Enhancing brand equity through sponsorship allows firms to charge higher prices for their products and this way generating monetary benefits of sponsorship (Henseler at al., 2011). Another desired result of increasing consumer-based brand equity would be to increase behavioural brand loyalty (Romaniuk \& Nenycz-Thiel, 2011).

- Perceived social responsibility of the brand

Perceived social value as a result of collaboration in sports creates benefits for companies when people believe that collaboration actions are socially responsible and sincere actions to further social goals. These believes reflect the cognitive category of consumers' attitudes. 
Green and Peloza (2011) studied the effects how social responsibility creates value for consumers and discovered that improving social responsibility in a company might provide three types of benefits for customers: emotional, social and functional. Social benefit is also created in case there is a judgement of the decision that the customer makes and therefore pressure to choose socially acceptable alternative is produced.

Surveys indicate that even in the earlier stages of collaboration customers tend to positively respond toward brands supporting nonprofit initiatives (Austin \& Seitanidi, 2012a; Seitanidi \& Austin, 2014). Moreover, following the Collaboration Continuum logic, the benefits of collaboration become gradually greater and more visible when moving from philanthropic stage of collaboration to integrative stage (Austin, 2000; Seitanidi \& Austin, 2014).

Building on abovementioned findings the following research question was proposed: Are the perceived benefits of sponsorship agreement between the company and sports club growing while moving from the philanthropic through transactional to integrative stage? In order to answer the research question the following hypotheses have been proposed:

H1: Perceived benefits in philanthropic stage are smaller than in transactional stage.

H2: Perceived benefits in transactional stage are smaller than in integrative stage.

\section{Research method}

In order to measure consumers' attitudes towards a company as a result of cross-sectoral collaboration a comprehensive questionnaire was designed. Attitudes towards company were represented by three constructs: "Brand favourability", "Use of products" and "Perceived social input". Each construct was measured with two to three questions using 6-point Likert scale. The composition of constructs created are presented in Table 2.

For the purpose of this research, three fictional scenarios have been created, to depict a cross-sectoral collaboration scenario on each collaboration stage. The respondents answered to three different scenarios with same questions measuring the three constructs of attitudes 
towards the company. All of these scenarios involve a fictional football club that is the sport entity representing a non-profit side of collaboration. In the first two cases, the business partner is a producer of groceries and in the third case - a producer of sports equipment. The purpose for using a producer of groceries was to provide a scenario where the threshold for the customer to change brand/company preference or try out new products was as low as possible. For the last case the business was changed to a producer of sports equipment, to depict the increased alignment between the business and the non-profit organization.

The three scenarios created and presented in the questionnaire were the following:

Case 1 (Philanthropic stage): Company $\mathrm{X}$ is a local producer of groceries and has donated $5000 €$ to support a football club to host a youth tournament. The company $\mathrm{X}$ was mentioned in the football tournament's leaflet and website as a contributor.

Case 2 (Transactional stage): Company $\mathrm{X}$ is a domestic producer of groceries and has signed a one-year contract for $100000 €$ with a football club that competes on the highest national level. In return company $\mathrm{X}$ receives company logos on the players' jerseys and large banners to the club's home stadium, which will gain exposure through TV broadcast from the matches.

Case 3 (Integrative stage): Company $\mathrm{X}$ is a domestic producer of sports equipment and engages in a collaboration in which the company provides sporting equipment for a local football club and uses data from the players to develop their products in order to provide best solutions for players and consumers. The company also provides monetary support to the club and receives the right to use club's logo and name in marketing their products and similar exposure than in case 2 (shirt logos and banners). The total expenditure of this collaboration is around $1000000 €$.

\section{Research data analysis}

The survey was conducted in February 2020 as an open link internet survey. The sampling method was snowball sampling where research participants recruit other participants for the study. In total, the survey resulted in a sample size of $n=105$. The gender distribution was pretty even with 55 males and 46. Age of the respondents varied between 18 
to 60 years. A significant number of respondents were between 18 to 25 , covering $81 \%$ of the total amount. Age group from 26 to 40 years old were clearly underrepresented in the survey covering under $8 \%$ of all the participants. In the category of over 40-year-old there were also a representation of $11 \%$, therefore the study took into consideration a broad age range but due to the sampling method the emphasis of the respondents is on the younger population.

In the first stage of data analysis, a reliability analysis was conducted by calculating the Cronbach's alphas for each of the nine scales created providing values presented in Table 1.

Table 1. Reliability analysis of scales

\begin{tabular}{lllll}
\hline & & $\begin{array}{l}\text { Case 1 } \\
\text { Philanthropic } \\
\text { stage }\end{array}$ & $\begin{array}{l}\text { Case 2 } \\
\text { Transactional } \\
\text { stage }\end{array}$ & $\begin{array}{l}\text { Case 3 } \\
\text { Integrative } \\
\text { stage }\end{array}$ \\
\hline Construct & $\begin{array}{l}\text { No. } \\
\text { Items }\end{array}$ & $\begin{array}{l}\text { Cronbach's } \\
\text { Alpha }(\alpha)\end{array}$ & $\begin{array}{l}\text { Cronbach's } \\
\text { Alpha }(\alpha)\end{array}$ & $\begin{array}{l}\text { Cronbach's } \\
\text { Alpha }(\alpha)\end{array}$ \\
\hline Brand Favourability & 3 & 0.852 & 0.902 & 0.929 \\
\hline Use of Products & 2 & 0.820 & 0.851 & 0.858 \\
\hline Social Input & 3 & 0.815 & 0.818 & 0.780 \\
\hline
\end{tabular}

Source: own elaboration.

In the results, every scale provided a Cronbach's alpha value where $\alpha>0.78$ so they can all be considered very reliable and can be used in the research. The second part of the data analysis was to measure relevance of each individual question for the scale. This was completed by calculating new alpha values for each scale if a particular question was removed. Results of this test can be seen in Table 2 and they did not suggest any questions in the created scales to be eliminated as every value of alpha would have decreased or remained the same with the removal of any question.

The descriptive statistics presented in Table 3 show the results of the survey. The changes in perceived benefits are also presented in Figure 2. From the graph it can be seen that the averages tended to be higher in Case 1 (philanthropic), they decreased significantly in Case 2 (transactional) and then increased again for Case 3 (integrative).

In order to verify the statistical importance of the differences in perceived benefits between the stages of cooperation, the repeated 
Table 2. Constructs composition and reliability

\begin{tabular}{|c|c|c|c|c|}
\hline & & $\begin{array}{l}\text { Case } 1 \\
\text { Philanthropic }\end{array}$ & $\begin{array}{l}\text { Case } 2 \\
\text { Transactional }\end{array}$ & $\begin{array}{l}\text { Case } 3 \\
\text { Integrative }\end{array}$ \\
\hline Construct: & $\begin{array}{l}\text { No. } \\
\text { Items }\end{array}$ & $\begin{array}{l}\text { Alpha }(\alpha) \text { if } \\
\text { removed }\end{array}$ & $\begin{array}{l}\text { Alpha }(\alpha) \text { if } \\
\text { removed }\end{array}$ & $\begin{array}{l}\text { Alpha }(\alpha) \text { if } \\
\text { removed }\end{array}$ \\
\hline Brand Favourability & 3 & 0.852 & 0.902 & 0.929 \\
\hline $\begin{array}{l}\text { 1. This sponsorship would } \\
\text { make me more favourable } \\
\text { towards the brand }\end{array}$ & & 0.801 & 0.905 & 0.912 \\
\hline $\begin{array}{l}\text { 2. This sponsorship would } \\
\text { improve my perception of } \\
\text { the sponsor }\end{array}$ & & 0.758 & 0.840 & 0.896 \\
\hline $\begin{array}{l}\text { 3. This sponsorship would } \\
\text { make me like the sponsor } \\
\text { more }\end{array}$ & & 0.819 & 0.829 & 0.882 \\
\hline Use of Products & 2 & 0.820 & 0.851 & 0.858 \\
\hline $\begin{array}{l}\text { 1. This sponsorship } \\
\text { would make me consider } \\
\text { sponsor's products }\end{array}$ & & - & - & - \\
\hline $\begin{array}{l}\text { 2. This sponsorship would } \\
\text { make me more likely to } \\
\text { consider sponsors' products } \\
\text { next time I buy }\end{array}$ & & - & - & - \\
\hline Social Input & 3 & 0.815 & 0.818 & 0.780 \\
\hline $\begin{array}{l}\text { 1. In my opinion the } \\
\text { sponsor thinks the club } \\
\text { needs support }\end{array}$ & & 0.777 & 0.728 & 0.782 \\
\hline $\begin{array}{l}\text { 2. In my opinion the } \\
\text { sponsor has the interest of } \\
\text { sport at heart }\end{array}$ & & 0.699 & 0.698 & 0.661 \\
\hline $\begin{array}{l}\text { 3. In my opinion this } \\
\text { sponsor would probably } \\
\text { support the cause even if it } \\
\text { had a lower profile }\end{array}$ & & 0.758 & 0.811 & 0.646 \\
\hline
\end{tabular}

Source: own elaboration. 
Table 3. Descriptive statistics

\begin{tabular}{llll}
\hline & Mean & Std. Deviation & N \\
\hline Case 1 Favourability & 4.3429 & 1.00899 & 105 \\
\hline Case 2 Favourability & 3.5079 & 0.99367 & 105 \\
\hline Case 3 Favourability & 4.1587 & 1.05419 & 105 \\
\hline Case 1 Use of Products & 3.7810 & 0.02826 & 105 \\
\hline Case 2 Use of Products & 3.3000 & 1.01100 & 105 \\
\hline Case 3 Use of Products & 4.0571 & 1.08378 & 105 \\
\hline Case 1 Social Input & 3.8254 & 1.11717 & 105 \\
\hline Case 2 Social Input & 2.7619 & 1.12917 & 105 \\
\hline Case 3 Social Input & 3.6603 & 1.21157 & 105 \\
\hline
\end{tabular}

Source: own elaboration

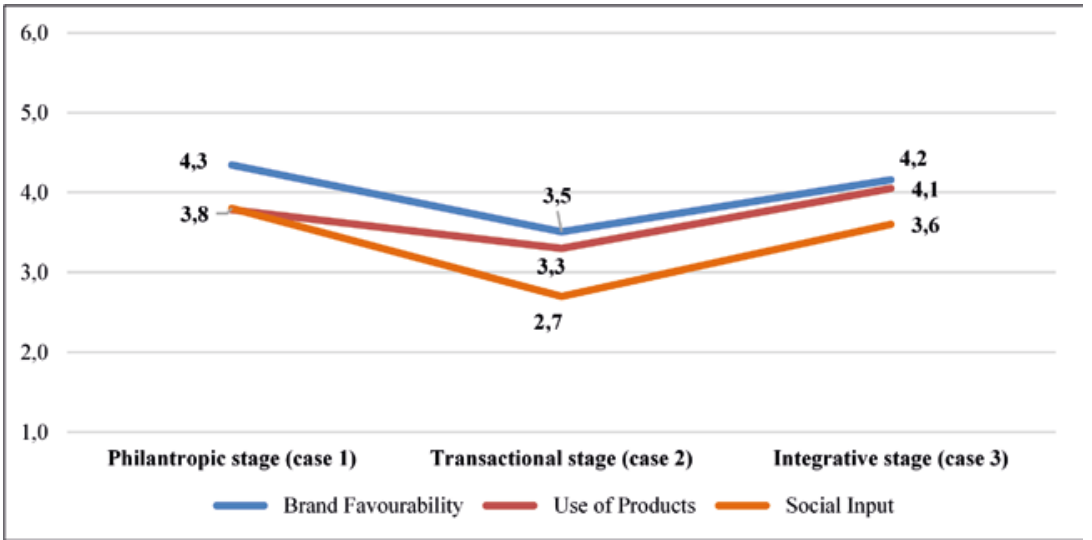

Figure 2 Perceived benefits for the three cooperation stages on 6-point Likert scale Source: own elaboration 
measures test was conducted on 95\% confidence level to test the similarity of the means, and the results are shown in table 4 .

Table 4. Repeated measures test

\begin{tabular}{|c|c|c|c|c|c|c|c|}
\hline Source & Measure & & $\begin{array}{l}\text { Type III Sum } \\
\text { of Squares }\end{array}$ & df & $\begin{array}{l}\text { Mean } \\
\text { Square }\end{array}$ & $\mathbf{F}$ & Sig. \\
\hline \multirow[t]{3}{*}{ Case } & $\begin{array}{l}\text { Brand } \\
\text { Favourability }\end{array}$ & $\begin{array}{l}\text { Sphericity } \\
\text { Assumed }\end{array}$ & 40.408 & 2 & 20.204 & 40.251 & .000 \\
\hline & $\begin{array}{l}\text { Use of } \\
\text { Products }\end{array}$ & $\begin{array}{l}\text { Sphericity } \\
\text { Assumed }\end{array}$ & 30.830 & 2 & 15.415 & 26.353 & .000 \\
\hline & Social Input & $\begin{array}{l}\text { Sphericity } \\
\text { Assumed }\end{array}$ & 68.789 & 2 & 34.395 & 43.498 & .000 \\
\hline \multirow[t]{3}{*}{$\begin{array}{l}\text { Error } \\
\text { (Case) }\end{array}$} & $\begin{array}{l}\text { Brand } \\
\text { Favourability }\end{array}$ & $\begin{array}{l}\text { Sphericity } \\
\text { Assumed }\end{array}$ & 104.406 & 208 & .502 & & \\
\hline & $\begin{array}{l}\text { Use of } \\
\text { Products }\end{array}$ & $\begin{array}{l}\text { Sphericity } \\
\text { Assumed }\end{array}$ & 121.670 & 208 & .585 & & \\
\hline & Social Input & $\begin{array}{l}\text { Sphericity } \\
\text { Assumed }\end{array}$ & 164.470 & 208 & .791 & & \\
\hline
\end{tabular}

Source: own elaboration.

The test results indicate that for every construct, brand favourability, use of products and perceived social input, there is a statistically significant difference between the measures when moving from Case 1 to Case 2 and from Case 2 to Case 3. For brand favourability, the test found a statistical significance, $\mathrm{F}(2,208)=40.251, \mathrm{p}=.000$ on a 95\% confidence level. For use of products, a statistical significant effect of collaboration stage was found, $F(2,208)=26.353, p=.000$. Also a statistically significant effect for perceived social input was discovered $\mathrm{F}(2,208)=43.498, \mathrm{p}=.000$.

The difference between Cases 1 and 3 was tested for significant difference on $95 \%$ confidence level, using a paired sample T-Test. The results of the test are presented in Table 5.

A statistically significant difference was found in use of products between Case 1 and Case 3 with $\mathrm{T}=-2.439, \mathrm{p}=0.016$. But contradicting to expectations there was no statistical significance in perceived social input between Cases 1 and 3 with $\mathrm{T}=1.275 \mathrm{p}=0.205$. Also, brand favourability did not provide statistically significant difference between Cases 1 and 3 on the $95 \%$ confidence level resulting in $\mathrm{T}=1.813 \mathrm{p}=$ 0.073 
Table 5. Paired samples T-Test

\begin{tabular}{lllllllllll}
\hline & \multicolumn{7}{c}{$\begin{array}{c}\text { 95\% Confidence } \\
\text { Interval of the Difference }\end{array}$} \\
\hline & Mean & $\begin{array}{l}\text { Std. } \\
\text { Deviation }\end{array}$ & $\begin{array}{l}\text { Std. } \\
\text { Error } \\
\text { Mean }\end{array}$ & Lower & Upper & t & df & $\begin{array}{l}\text { Sig. } \\
\text { (2-tailed) }\end{array}$ \\
\hline Pair 1 & $\begin{array}{l}\text { Case1_Favourability - } \\
\text { Case3_Favourability }\end{array}$ & .18413 & 1.04081 & .10157 & -.01730 & .38555 & 1.813 & 104 & .073 \\
\hline Pair 2 & $\begin{array}{l}\text { Case1_Use - } \\
\text { Case3_Use }\end{array}$ & -.27619 & 1.16020 & .11322 & -.50072 & -.05166 & -2.439 & 104 & .016 \\
\hline Pair 3 & $\begin{array}{l}\text { Case1_Input - } \\
\text { Case3_Input }\end{array}$ & .16508 & 1.32620 & .12942 & -.09157 & .42173 & 1.275 & 104 & .205 \\
\hline
\end{tabular}

Source: own elaboration

\section{Findings and conclusions}

The results of the study do not fully support the assumption that the perceived benefits of collaboration are growing while moving from the philanthropic through transactional to integrative form of sponsorship agreement. The $\mathrm{H} 1$ hypothesis is not supported as the perceived benefits in philanthropic stage resulted higher than in transactional stage. However the $\mathrm{H} 2$ hypothesis is confirmed by the study that indicated that the perceived benefits in transactional stage are smaller than in integrative stage. Despite the benefits were not continuously growing from one collaboration stage to another, the research found evidence that there is a statistically significant difference in the benefits when moving from philanthropic collaboration towards the integrative stage. Therefore, it is safe to say that collaboration stage has an effect on the benefits received as a result of the collaboration.

Moving on to individual measures for each of the scales created for this research, the three constructs reflecting consumer attitudes towards companies involved in sport sponsorship will be discussed.

From all of the three benefits studied, brand favourability was positively affected the most through every collaboration stage. The highest level of brand favourability was gained as a result of philanthropic collaboration and a similar result without statistically significant difference was gained in the integrative stage. Transactional collaboration also gained a fair amount of brand favourability but not as effectively as the other two stages. 
The use of products was the second most affected benefit of the three studied. The highest use of products was reached in the integrative stage of collaboration. This can be explained by the nature of the collaboration on that stage, where entities try to create additional value as a result of collaboration (Austin, 2000). Therefore, customers could benefit from the additional value created when using company's products. The second highest level in use of products was achieved in the philanthropic stage while the transactional stage resulted in the lowest use of products.

Perceived social input was the least affected benefit of the all three studied, indicating that it was the most difficult to gain as a result of any collaboration. Perceived social input was affected the most in the philanthropic stage of collaboration which can be explained by its close association with charitable giving. The integrative stage of collaboration provided the second-best level of perceived social input with no statistically significant difference to the philanthropic stage. The transactional stage was seen to provide the least social input at a surprisingly low level compared to other stages of collaboration. This might be because transactional collaboration can be seen as a mere business activity and previous researches have also found that companies sometimes enter transactional collaboration for selfish reasons (Selsky \& Parker, 2010).

The research was unable to prove a statistical significance in brand favourability and perceived social input between philanthropic and integrative stages of collaboration. This result can be somewhat misleading due to limitations of the research architecture. In the questionnaire, the amount of exposure was disregarded and respondents were equally exposed to every type of collaboration. Previous studies show however that the amount of exposure can positively affect the brand preference (Olson \& Thjomoe, 2003; Bornstein, 1989). As collaboration in the integrative stage usually reaches a larger part of consumers attention due to the larger scale of actions compared to the philanthropic stage (Austin, 2000), it can be assumed that the total amount of benefits in the integrative stage would outperform the benefits from smaller scale philanthropic collaboration. It should be also noted that the three cases reflecting the three cooperation stages were also associated with different company sizes, from the smallest for philanthropic to the biggest for integrative stage case. Therefore the respondents' answers may include different 
attitudes towards not only type of cooperation but also strength and size of the company involved in the sponsorship. Hence, the research results may be biased by the company size which was not the intention of the study.

Having in mind the abovementioned limitations, it is still possible to drive several recommendations for businesses of different sizes. A high level of benefits received in the philanthropic stage suggests that it can be favourable for small and medium sized companies with smaller budgets to engage in philanthropic collaboration. This somewhat contradicts with Zinger and O'Reilly (2010) who suggest also small businesses to move away from philanthropic collaboration as fast as possible. But with the evidence from this research, it can be suggested that small companies which cannot afford to engage in large scale integrative collaboration could create as favourable response as integrative collaboration but with a smaller budget and for smaller audience in the philanthropic stage. Although, it is yet to be determined whether the exposure in the philanthropic stage is working effectively enough to cover the costs of collaboration, the response from the informed customers seems to be favourable.

From the viewpoint of larger companies, firms that are able to fully engage in integrative collaboration with sport are likely to receive higher overall impact than in the philanthropic stage. The higher overall impact is possible due to the high level of additional value created in the collaboration which has been discussed by Austin (2000), and Seitanidi and Austin (2014). The results of the study clearly show that specially companies that perform the transactional type of collaboration should move towards integrative stage in order to produce customers' positive attitudes towards their brands.

The study presented should be treated as a preliminary one and further research in the field is necessary to fully understand the phenomenon analysed. As suggested by Austin and Seitanidi (2012b), it is important to further disclose how the two partners in cross-sectoral collaboration view their own and others' costs and benefits. This is an area where this research also tries to contribute to the understanding of benefits for the business partners. Secondly, it is important to conduct further research that avoids the sponsors' size bias in responses and takes into consideration the amount of exposure on the different collaboration stages. As the study focused on younger customers and their attitudes toward football club activities, representative sampling 
and researching different types of sponsors is needed to confirm the validity of the results for other settings.

\section{References}

Aaker, D. A. (1991), Managing Brand Equity: Capitalizing on the Value of a Brand Name. New York: Free Press.

Austin, J. E. \& Seitanidi, M. M. (2012a). Collaborative value creation: A Review of partnering between nonprofits and businesses: Part I. Value creation spectrum and collaboration stages. Nonprofit and Voluntary Sector Quarterly, 41(5), 726-758.

Austin, J. E. \& Seitanidi, M. M. (2012b). Collaborative value creation: A review of partnering between nonprofits and businesses. Part 2: Partnership processes and outcomes. Nonprofit and Voluntary Sector Quarterly, 41(6), 929-968.

Austin, J. E. (2000). Strategic collaboration between nonprofits and businesses. Nonprofit and Voluntary Sector Quarterly, 29(1), 69-97.

Barroso-Méndez, M. J., Galera-Casquet, C., Seitanidi, M. M., \& Valero-Amaro, V. (2016). Cross-sector social partnership success: A process perspective on the role of relational factors. European Management Journal, 34, 674-685.

Bornstein, R. F. (1989). Exposure and effect: Overview and meta-analysis of research, 1968-1987. Psychological Bulletin, 106(2), 265-289.

Breckler, S. J. (1984). Empirical validation of affect, behavior, and cognition as distinct components of attitude. Journal of Personality and Social Psychology, 47(6), 1191-1205.

Bryson, J. M., Crosby, B. C. \& Stone, M. M. (2006). The design and implementation of cross-sector collaborations: Propositions from the literature. Public Administration Review, 66(1), 44-55.

Cornwell, T. B., Roy, D. P. \& Steinard, E. A. (2001). Exploring managers’ perceptions of the impact of sponsorship on brand equity. Journal of Advertising, 30(2), 41-51.

Davies, J., Daellenbach, K. \& Ashill, N. J. (2008). Value in a multiple perspective view of sports sponsorship. International Journal of Sport Management and Marketing, 3(3), 184-200.

Green, T. \& Peloza, J. (2011). How does corporate social responsibility create value for consumers? Journal of Consumer Marketing, 28(1), 48-56.

Henseler, J., Wilson, B. \& Westberg, K. (2011). Managers' perceptions of the impact of sport sponsorship on brand equity: Which aspects of the sponsorship matter most? Sport Marketing Quarterly, 20(1), 7-21.

Heyman, D. R. (Ed.) (2011), Nonprofit Management 101: A Complete and Practical Guide for Leaders and Professionals. San Francisco: Jossey-Bass.

IEG Sponsorship (2015). Sponsorship Spending Report. Retrieved from https://www. sponsorship.com/ieg/files/4e/4e525456-b2b1-4049-bd51-03d9c35ac507.pdf

International Olympic Committee Marketing Report Rio 2016 (2016). Retrieved from https://stillmed.olympic.org/media/Document\%20Library/OlympicOrg/Games/ Summer-Games/Games-Rio-2016-Olympic-Games/Media-Guide-for-Rio-2016/ IOC-Marketing-Report-Rio-2016.pdf.

Le Ber, M. J. \& Branzei, O. (2010). (Re)forming strategic cross-sector partnerships: Relational processes of social innovation. Business \& Society, 49(1), 140-172. 
Lefroy, K., \& Tsarenko, Y. (2013). From receiving to achieving: The role of relationship and dependence for nonprofit organizations in corporate partnerships. European Journal of Marketing, 47(10), 1641-1666.

Maldonado-Erazo, C., Durán-Sánchez, A. \& Álvarez-García, J. (2019). Sports sponsorship: Scientific coverage in academic journals. Journal of Entrepreneurship and Public Policy, 8(1), 163-186.

McDonald, S. \& Young, S. (2012). Cross-sector collaboration shaping corporate social responsibility best practice within the mining industry. Journal of Cleaner Production, 37, 54-67.

Meenaghan, T. (1991). The role of sponsorship in the marketing communications mix. International Journal of Advertising, 10, 35-47.

Murphy, M., Arenas, D., \& Batista, J. M. (2015). Value creation in cross-sector collaborations: The roles of experience and alignment. Journal of Business Ethics, 130(1), 145-162.

Olson, E. L. \& Thjomoe, H. M., (2003). The effects of peripheral exposure to information on brand preference. European Journal of Marketing, 37(1-2), 243-255.

Ramchandani, G., Coleman, R. J. \& Bingham, J. (2017). Sport participation behaviours of spectators attending major sports events and event induced attitudinal changes towards sport. International Journal of Event and Festival Management, 8(2), 121-135.

Romaniuk, J. \& Nenycz-Thiel, M. (2013). Behavioral brand loyalty and consumer brand associations. Journal of Business Research, 66(1), 67-72.

Seitanidi, M. \& Austin, J. (2014). Creating Value in Nonprofit-Business Collaborations: New Thinking and Practice. San Francisco: Jossey-Bass.

Seitanidi, M. M., Ryan, A. \& Woodliffe, L. (2007). A critical review of forms of corporate community involvement: From philanthropy to partnerships. International Journal of Nonprofit and Voluntary Sector Marketing, 12(3), 247-266.

Selsky, J. \& Parker, B. (2010). Platforms for cross-sector social partnerships: Prospective sensemaking devices for social benefit. Journal of Business Ethics, 94, 21-37.

Speed, R. \& Thompson, P. (2000). Determinants of sports sponsorship response. Journal of the Academy of Marketing Science, 28(2), 226-238.

Tsordia, C., Papadimitriou, D. \& Parganas, P. (2018). The influence of sport sponsorship on brand equity and purchase behavior. Journal of Strategic Marketing, 26(1), 85-105.

Zinger, J. T. \& O’Reilly, N. J. (2010). An examination of sports sponsorship from a small business perspective. International Journal of Sports Marketing \& Sponsorship, 11(4), 283-301. 
